\title{
THE MECHANISM OF POTASSIUM EXCRETION IN THE CHICKEN
}

\author{
By JACK ORLOFF AND DOUGLAS G. DAVIDSON \\ (From the Laboratory of Kidney and Electrolyte Metabolism, National Heart Institute, \\ Bethesda, Md.)
}

(Submitted for publication June 23, 1958; accepted September 4, 1958)

The mechanism of potassium excretion by the kidney has been investigated in a number of species $(1,2)$. Although much information has been deduced from these studies, including an analysis of the probable intra- and peritubular events involved, the interpretation of results has often been complicated by extrarenal effects induced by the experimental procedures. In order to obviate these difficulties and to provide information on the role of alterations in the peritubular concentrations of electrolytes in the process, some of the phenomena relating to the renal excretion of potassium have been reinvestigated in a direct fashion in the chicken.

Chickens possess a functioning renal-portal circulation (3). Blood from the leg vein drains directly into the postglomerular peritubular vessels on that side, and then enters the systemic circulation via the vena cava. The glomerulus is thereby bypassed in the first circulation. It is possible to investigate agents which exert effects on tubule cells by administering the test substance in one leg and comparing urine from the kidney of the infused side with that from the contralateral kidney which serves as a control. This procedure, originally devised by Sperber (4), minimizes the role of glomerular filtration. It permits one to achieve concentrations of test substance in peritubular blood of the experimental side which would be lethal in the systemic circulation. Furthermore the concentration of test substance on the injected side is always greater than in peritubular blood of the contralateral control kidney.

\section{METHODS}

Rhode Island Red hens weighing approximately 2 to 4 $\mathrm{Kg}$. each were used in all studies. The procedure was essentially that of Sperber (4). Animals were suspended in the upright position in a cloth sling. Food was withdrawn for 12 to 18 hours prior to all studies. To insure adequacy of urine flow in control periods, 80 to $100 \mathrm{ml}$. of water was administered by crop tube at the beginning of each study.

All solutions were administered intravenously by means of a Bowman constant infusion pump. Infusions into the renal-portal venous system of the experimental side were introduced by means of a polyethylene catheter in the saphenous vein of that side. Infusions directly into the systemic circulation were administered through the wing vein.

Urine was collected separately from each ureter by means of small polyethylene funnels sewn directly over the individual ureteral openings in the cloaca. Urine from the kidney of the injected side is referred to in tables and figures as being from the "experimental side"; that from the contralateral kidney, the "control side." Blood for analyses was drawn into oiled heparinized syringes at the midpoint of alternate periods from either the leg, wing or neck veins.

Glomerular filtration rate was estimated by the clearance of inulin. The clearance of inulin was independent of the site of infusion when the inulin was infused into either of the leg veins or directly into the systemic circulation via the wing vein.

Renal plasma flow was measured by the clearance of para-aminohippurate (PAH). This averaged approximately $50 \mathrm{ml}$. per minute per side in $2 \mathrm{Kg}$. chickens. Solutions of PAH were injected into the wing vein.

Inulin was measured in plasma and urine by the method of Walser, Davidson and Orloff (5), PAH in either whole blood or plasma and urine by the method of Bratton and Marshall (6). Sodium and potassium in plasma and urine were determined by flame photometry, urine chloride by a modified Volhard titration or potentiometry (7). The $\mathrm{pH}$ of urine was measured in a Beckman Model $\mathrm{G} \mathrm{pH}$ meter at room temperature or in a Cambridge Research model $\mathrm{pH}$ meter at $37^{\circ} \mathrm{C}$. Total $\mathrm{CO}_{2}$ was determined by the method of Van Slyke and Neill (8).

The peritubular concentration of potassium was estimated as the sum of the peripheral venous potassium concentration plus

$$
\frac{\text { potassium injected ( } \mu \mathrm{M} \text { per minute) }}{\text { renal plasma flow (ml. per minute) }}{ }^{1}
$$

1 The calculation of the peritubular concentration of potassium is only a first approximation. It has not been possible to determine with any degree of accuracy the precise volume flow of peritubular plasma; consequently, 
TABLE I

Effect of $\mathrm{K}_{2} \mathrm{SO}_{4}$ on electrolyte excretion

\begin{tabular}{|c|c|c|c|c|c|c|c|c|c|c|c|c|c|c|}
\hline \multirow[b]{2}{*}{$\begin{array}{l}\text { Time } \\
\text { min. }\end{array}$} & \multirow{2}{*}{$\begin{array}{c}\text { Plasma } \\
\mathrm{K}^{+} \\
m E q . / L .\end{array}$} & \multicolumn{6}{|c|}{ Control kidney } & \multirow{2}{*}{$\underset{m E q . / L .}{\mathrm{K}^{+} \mathbf{T}}$} & \multicolumn{6}{|c|}{ Experimental kidney } \\
\hline & & $\underset{m l . / m i n}{\text { GFR }}$ & $\mathrm{pH}$ & $\mathrm{U}_{\mathrm{NaV}}$ & $\begin{array}{c}\mathrm{UkV} \\
\text { Eq./min. }\end{array}$ & UclV & $\mathrm{E} / \mathrm{F}^{*}$ & & $\underset{\text { ml. } / \text { min }}{\overline{G R}}$ & $\mathrm{pH}$ & $\mathrm{UNaV}_{\mu}$ & $\underset{E q . / m i n}{U K V}$. & $\mathrm{UalV}$ & $\mathrm{E} / \mathrm{F}^{*}$ \\
\hline-30 & \multicolumn{14}{|c|}{$\begin{array}{l}\text { Infuse } 1.5 \mathrm{mg} . / \mathrm{min} \text {. inulin in } 5 \% \text { dextrose in } \mathrm{H}_{2} \mathrm{O} \text { at } .22 \mathrm{ml} . / \mathrm{min} \text {. into wing vein. } \\
\text { Priming inulin } 160 \mathrm{mg} \text {. }\end{array}$} \\
\hline $\begin{array}{c}0-9 \\
9-17 \\
33-49\end{array}$ & $\begin{array}{l}3.3 \\
3.3 \\
3.3\end{array}$ & $\begin{array}{l}7.0 \\
6.0 \\
6.0\end{array}$ & $\begin{array}{l}5.76 \\
5.74 \\
5.48\end{array}$ & $\begin{array}{l}2 \\
2 \\
4\end{array}$ & $\begin{array}{l}5 \\
4 \\
4\end{array}$ & $\begin{array}{l}.3 \\
.1 \\
.1\end{array}$ & $\begin{array}{l}.21 \\
.19 \\
.19\end{array}$ & $\begin{array}{l}3.3 \\
3.3 \\
3.3\end{array}$ & $\begin{array}{l}6.5 \\
6.0 \\
5.1\end{array}$ & $\begin{array}{l}5.83 \\
5.85 \\
5.58\end{array}$ & $\begin{array}{l}2 \\
2 \\
4\end{array}$ & $\begin{array}{l}5 \\
4 \\
4\end{array}$ & $\begin{array}{l}.5 \\
.3 \\
.1\end{array}$ & $\begin{array}{l}.22 \\
.18 \\
.21\end{array}$ \\
\hline 50 & \multicolumn{14}{|c|}{ Infuse $100 \mu \mathrm{M} / \mathrm{min}$. of $\mathrm{K}_{2} \mathrm{SO}_{4}$ into leg vein (experimental side) } \\
\hline $\begin{array}{c}55-65 \\
65-78 \\
78-89 \\
89-99 \\
99-109 \\
110-120\end{array}$ & $\begin{array}{l}4.3 \\
4.9 \\
5.2 \\
5.5 \\
5.8 \\
6.1\end{array}$ & $\begin{array}{l}4.8 \\
4.3 \\
5.2 \\
5.1 \\
5.2 \\
6.2\end{array}$ & $\begin{array}{l}5.05 \\
5.46 \\
5.71 \\
5.19 \\
5.74 \\
5.75\end{array}$ & $\begin{array}{l}12 \\
21 \\
30 \\
36 \\
38 \\
49\end{array}$ & $\begin{array}{r}9 \\
30 \\
50 \\
55 \\
70 \\
84\end{array}$ & $\begin{array}{r}1 \\
2 \\
10 \\
14 \\
19 \\
28\end{array}$ & $\begin{array}{r}.42 \\
1.44 \\
1.83 \\
1.98 \\
2.31 \\
2.30\end{array}$ & $\begin{array}{r}7.7 \\
8.5 \\
8.8 \\
9.5 \\
10.0 \\
11.1\end{array}$ & $\begin{array}{l}4.1 \\
4.0 \\
4.8 \\
5.4 \\
5.0 \\
5.2\end{array}$ & $\begin{array}{l}6.06 \\
6.76 \\
6.88 \\
6.19 \\
6.69 \\
6.82\end{array}$ & $\begin{array}{l}15 \\
28 \\
52 \\
39 \\
43 \\
52\end{array}$ & $\begin{array}{l}29 \\
64 \\
87 \\
81 \\
91 \\
96\end{array}$ & $\begin{array}{r}3 \\
27 \\
45 \\
36 \\
34 \\
39\end{array}$ & $\begin{array}{l}1.67 \\
3.26 \\
3.48 \\
2.72 \\
3.12 \\
3.03\end{array}$ \\
\hline
\end{tabular}

* $\mathrm{E} / \mathrm{F}$ is the ratio of excreted to filtered potassium.

$\dagger \mathrm{P}-\mathrm{T}$ refers to peritubular plasma $\mathrm{K}^{+}$concentration.

RESULTS

\section{The effect of the infusion of potassium}

The infusion of potassium into one leg vein uniformly resulted in an increase in the rates of excretion of potassium, sodium and chloride. The effects were more marked on the side of the infusion (experimental kidney, Table I), due to the higher concentration of potassium in the peritubular blood of that side. In the study illustrated, urine $\mathrm{pH}$ rose and remained elevated on the experimental side. In others (see below) an initial unilateral rise in urine $\mathrm{pH}$ was followed by a decrease to or below control values. The excretion of potassium exceeded that filtered in Periods 4 through 9 on the experimental side and Periods 5 through 9 on the control side, evidence that potassium is secreted in the chicken as in other species examined. However unlike the situation in dog and man in which prior administration of potassium for a few days is generally necessary to elicit net secretion, the infusion of potassium into the leg vein of a chicken uniformly evokes this response.

Figure 1 illustrates the relationship between potassium excretion and the concentration of potassium in peritubular plasma. It can be seen that the rate of excretion is not a linear function of plasma concentration. This is also evident in Table I. At high plasma concentrations

total renal plasma flow has been used as an estimate of the minute volume of distribution of injected potassium. potassium excretion approaches a maximal rate which is relatively constant and only minimally affected by acute alterations in tubular load. In the study illustrated (Figure 1), $100 \mu \mathrm{M}$ per minute of potassium sulfate was injected into the leg vein. Potassium excretion increased rapidly at first, reached a maximum of approximately $65 \mu \mathrm{Eq}$. per minute and remained at this value despite a progressive increase in the calculated concentration of potassium in peritubular plasma from 9 to $12 \mu \mathrm{Eq}$. per $\mathrm{ml}$. No significant change in renal blood flow occurred on the experimental side. Blood flow averaged $53.3 \mathrm{ml}$. per minute in the control periods and 52.1 during the administration of potassium. The rate of potassium excretion rose on the control side as well, reaching approximately the same rate when the peripheral venous plasma concentration was also $9 \mu \mathrm{Eq}$. per ml, denoting that the tubular load on the control side was now equivalent to that at which "saturation" was achieved on the experimental side. Similar results were noted in three other studies. The rate of change of potassium excretion decreased markedly at high levels, approaching a limiting value in all studies. Changes in renal blood flow on this side were variable. In one, blood flow rose 25 per cent during the course of the infusion, in two a significant decrease occurred (43 and 9 per cent, respectively). Potassium excretion continued to rise on the control side despite similar changes in blood flow. Acute increases in the rate of potassium adminis- 


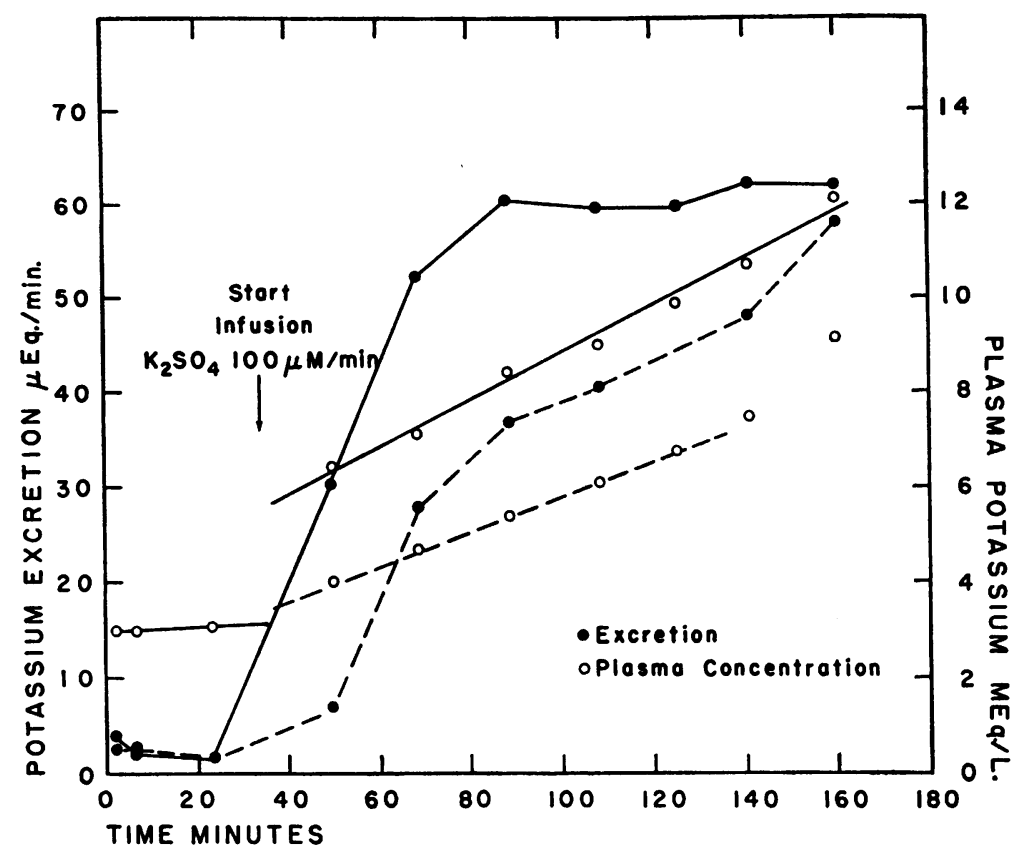

Fig. 1. The Relationship Between the Excretion of Potassium and the Peritubular Concentration of Potassium in Plasma

Continuous lines are for the experimental kidney; broken lines, control kidney.

Reprinted with permission of the University of Wisconsin Press, from Metabolic Aspects of Transport Across Cell Membranes, Q. R. Murphy, Ed., 1957, p. 216.

tration from 200 to $300 \mu \mathrm{Eq}$. per minute did not alter the steady state excretion by more than 10 $\mu$ Eq. per minute. It is apparent from these data that the accumulation of potassium in urine is not a consequence of simple diffusion from plasma.
At least one step in the process is apparently ratelimiting and capable of saturation

In the experiments noted in Table I and Figure 1 , potassium was administered as the sulfate salt. Results were qualitatively the same with

TABLE II

Effect of $\mathrm{Na}_{2} \mathrm{SO}_{4}$ on electrolyte excretion

\begin{tabular}{|c|c|c|c|c|c|c|}
\hline \multirow[b]{2}{*}{$\begin{array}{l}\text { Time } \\
\text { min. }\end{array}$} & \multicolumn{3}{|c|}{ Control kidney } & \multicolumn{3}{|c|}{ Experimental kidney } \\
\hline & $\mathrm{pH}$ & $\underset{\mu E q . / \text { min. }}{\mathrm{UNaV}_{\mathrm{NaV}}}$ & $\mathrm{UKV}_{\mathrm{K}}$ & $\mathrm{pH}$ & $\underset{\mu E q . / \min }{\mathrm{U}_{\mathrm{NaV}}}$ & $\mathrm{UKV}_{\mathbf{K}}$ \\
\hline-100 & \multicolumn{6}{|c|}{$\begin{array}{l}\text { Infuse } 1.5 \mathrm{mg} . / \mathrm{min} \text {. inulin in } 5 \% \text { dextrose in } \mathrm{H}_{2} \mathrm{O} \text { at } 0.25 \mathrm{ml} . / \mathrm{min} \text {. } \\
\text { into wing vein. Priming inulin } 150 \mathrm{mg} \text {. }\end{array}$} \\
\hline $\begin{array}{l}100-116 \\
116-131 \\
131-156\end{array}$ & $\begin{array}{l}5.47 \\
5.38 \\
5.16\end{array}$ & $\begin{array}{r}6 \\
10 \\
10\end{array}$ & $\begin{array}{l}5 \\
6 \\
4\end{array}$ & $\begin{array}{l}5.36 \\
5.08 \\
5.22\end{array}$ & $\begin{array}{r}7 \\
6 \\
10\end{array}$ & $\begin{array}{l}5 \\
4 \\
4\end{array}$ \\
\hline 157 & \multicolumn{6}{|c|}{ Infuse $100 \mu \mathrm{M} / \mathrm{min} . \mathrm{Na}_{2} \mathrm{SO}_{4}$ into leg vein (experimental side) } \\
\hline $\begin{array}{l}157-184 \\
185-203 \\
203-231 \\
231-244 \\
249-272 \\
272-284\end{array}$ & $\begin{array}{l}4.71 \\
4.85 \\
4.73 \\
4.74 \\
4.79 \\
4.92\end{array}$ & $\begin{array}{l}12 \\
14 \\
18 \\
21 \\
16 \\
23\end{array}$ & $\begin{array}{l}4 \\
4 \\
5 \\
5 \\
3 \\
5\end{array}$ & $\begin{array}{l}4.68 \\
4.70 \\
4.70 \\
4.67 \\
4.72 \\
4.59\end{array}$ & $\begin{array}{l}14 \\
16 \\
11 \\
20 \\
27 \\
21\end{array}$ & $\begin{array}{l}5 \\
5 \\
3 \\
5 \\
6 \\
4\end{array}$ \\
\hline
\end{tabular}


TABLE III

Effect of acetazoleamide on electrolyte excretion

\begin{tabular}{|c|c|c|c|c|c|c|c|c|c|c|}
\hline \multirow{3}{*}{$\begin{array}{c}\begin{array}{c}\text { Time } \\
\text { min. }\end{array} \\
0 \\
0\end{array}$} & \multirow[b]{2}{*}{ 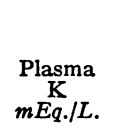 } & \multicolumn{4}{|c|}{ Control kidney } & \multicolumn{5}{|c|}{ Experimental kidney } \\
\hline & & $\underset{m l . / m i n}{\mathrm{GFR}}$ & $\mathrm{pH}$ & \multicolumn{2}{|c|}{$\underset{\mu E q . / m i n .}{\mathrm{U}_{\mathrm{NaV}}}$} & $\begin{array}{c}\text { Peri- } \\
\text { tubule K } \\
m E q . / L .\end{array}$ & $\underset{m l . / m i n}{\mathrm{GFR}}$ & $\mathrm{pH}$ & \multicolumn{2}{|c|}{$\underset{\mu E q . / \min .}{\mathrm{U}_{\mathrm{Na}}}$} \\
\hline & \multicolumn{10}{|c|}{$\begin{array}{l}\text { Infuse } 150 \mathrm{mg} \text {. inulin prime } \\
\text { Infuse } 1.5 \mathrm{mg} . / \mathrm{min} \text {. inulin, } 100 \mu \mathrm{M} / \mathrm{min} . \mathrm{K}_{2} \mathrm{SO}_{4} \text { into leg vein (experimental side) }\end{array}$} \\
\hline $\begin{array}{r}9-19 \\
20-40 \\
43-56 \\
57-63 \\
63-69 \\
69-77 \\
78-86\end{array}$ & $\begin{array}{l}5.25 \\
5.9 \\
6.6 \\
7.0 \\
7.2 \\
7.45 \\
7.7\end{array}$ & $\begin{array}{l}4.2 \\
3.6 \\
3.2 \\
3.3 \\
3.3 \\
3.4 \\
3.3\end{array}$ & $\begin{array}{l}5.94 \\
6.63 \\
5.98 \\
6.23 \\
6.04 \\
5.83 \\
6.13\end{array}$ & $\begin{array}{r}17 \\
8 \\
11 \\
15 \\
19 \\
17 \\
20\end{array}$ & $\begin{array}{l}40 \\
41 \\
47 \\
59 \\
57 \\
65 \\
68\end{array}$ & $\begin{array}{r}7.9 \\
9.4 \\
11.4 \\
12.0 \\
12.2 \\
12.3 \\
12.6\end{array}$ & $\begin{array}{l}4.0 \\
3.0 \\
3.0 \\
3.1 \\
3.3 \\
3.3 \\
3.2\end{array}$ & $\begin{array}{l}7.32 \\
7.44 \\
7.16 \\
6.88 \\
7.09 \\
6.88 \\
7.11\end{array}$ & $\begin{array}{l}34 \\
26 \\
23 \\
31 \\
41 \\
34 \\
35\end{array}$ & $\begin{array}{l}73 \\
67 \\
80 \\
81 \\
86 \\
87 \\
89\end{array}$ \\
\hline 84 & \multicolumn{10}{|c|}{ Infuse acetazoleamide, $5 \mathrm{mg} . / \mathrm{Kg} . / \mathrm{hr}$. into leg vein (experimental side) } \\
\hline $\begin{array}{c}86-92 \\
94-101 \\
101-112 \\
113-121 \\
122-129\end{array}$ & $\begin{array}{l}7.95 \\
8.25 \\
8.55 \\
8.8 \\
9.05\end{array}$ & $\begin{array}{l}3.4 \\
3.5 \\
2.8 \\
3.4 \\
3.8\end{array}$ & $\begin{array}{l}6.53 \\
6.78 \\
6.73 \\
6.54 \\
6.73\end{array}$ & $\begin{array}{l}37 \\
43 \\
40 \\
33 \\
48\end{array}$ & $\begin{array}{l}75 \\
94 \\
82 \\
83 \\
95\end{array}$ & $\begin{array}{l}11.7 \\
13.3 \\
13.8 \\
13.8 \\
14.2\end{array}$ & $\begin{array}{l}4.0 \\
4.2 \\
3.2 \\
3.4 \\
3.5\end{array}$ & $\begin{array}{l}7.15 \\
7.07 \\
7.11 \\
7.01 \\
7.12\end{array}$ & $\begin{array}{l}50 \\
46 \\
43 \\
41 \\
51\end{array}$ & $\begin{array}{l}92 \\
93 \\
87 \\
93 \\
99\end{array}$ \\
\hline
\end{tabular}

potassium chloride although the absolute rates of potassium excretion were not as great. The administration of equimolar amounts of sodium sulfate into one leg (Table II) resulted in no unilateral changes in urine composition; nor was any effect on potassium excretion demonstrable, indicating 1) the absence of a specific effect of sulfate ion on potassium transport, and 2), indirectly, that sulfate ion enters the urine largely, if not entirely, through the glomerulus. Similar results were noted in two other studies

The administration of a carbonic anhydrase inhibitor, acetazoleamide, elicits a response in the chicken (9) essentially similar to that observed in $\operatorname{dog}$ and man $(10,11)$. Five mg. per $\mathrm{Kg}$. per hour of acetazoleamide increases the excretion of potassium, sodium and bicarbonate, and elevates urine $\mathrm{pH}$ during the infusion of sodium chloride. Table III illustrates the effect of this dose on potassium excretion when the latter has been augmented to high rates by the prior administration of potassium sulfate. The administration of acetazoleamide was associated with an increase in potassium excretion on the experimental side of only $10 \mu \mathrm{Eq}$. per minute, a rise no greater than that occasionally observed in studies in which the rate of potassium infusion is acutely increased from 200 to $300 \mu \mathrm{Eq}$. per minute (see above). A somewhat greater augmentation of potassium excretion was observed on the control side. In one other study acetazoleamide did not elevate potassium excretion on the experimental side above the "maximal" rate induced by potassium sulfate administration despite a clearcut rise on the control side. It may be concluded that acetazoleamide is incapable of appreciably affecting the transport system for potassium once it has been "saturated" by prior injection of potassium. ${ }^{2}$

Alkalinization of the urine following the administration of potassium is observed in the chicken (Table I, Figure $2^{3}$ ) as in dog and man $(10,12,13)$. The decrease in hydrogen ion concentration is associated with a rise in potassium excretion and is presumably a consequence of the competitive nature of the mechanism by which hydrogen and potassium ions are secreted in exchange for sodium. This has been discussed in detail elsewhere (10). The importance of one other factor, the filtered load of bicarbonate, in the determination of urine $\mathrm{pH}$ is illustrated in Figure 2. Since bicarbonate reabsorption is effected by hydrogen ion secretion

2 It was not possible to demonstrate a unilateral effect of the inhibitor on urine composition when the drug was administered continuously. However, if urine was collected continuously by catheter irrigation, transient (10 to 15 minute) unilateral alkalinization on the infused side was noted when a single injection of $0.5 \mathrm{mg}$. of acetazoleamide was administered. It is apparent from this that the drug need not be filtered to exert its effect and may penetrate tubule cells from the contraluminal side.

3 The data are from the same study as Figure 1. 


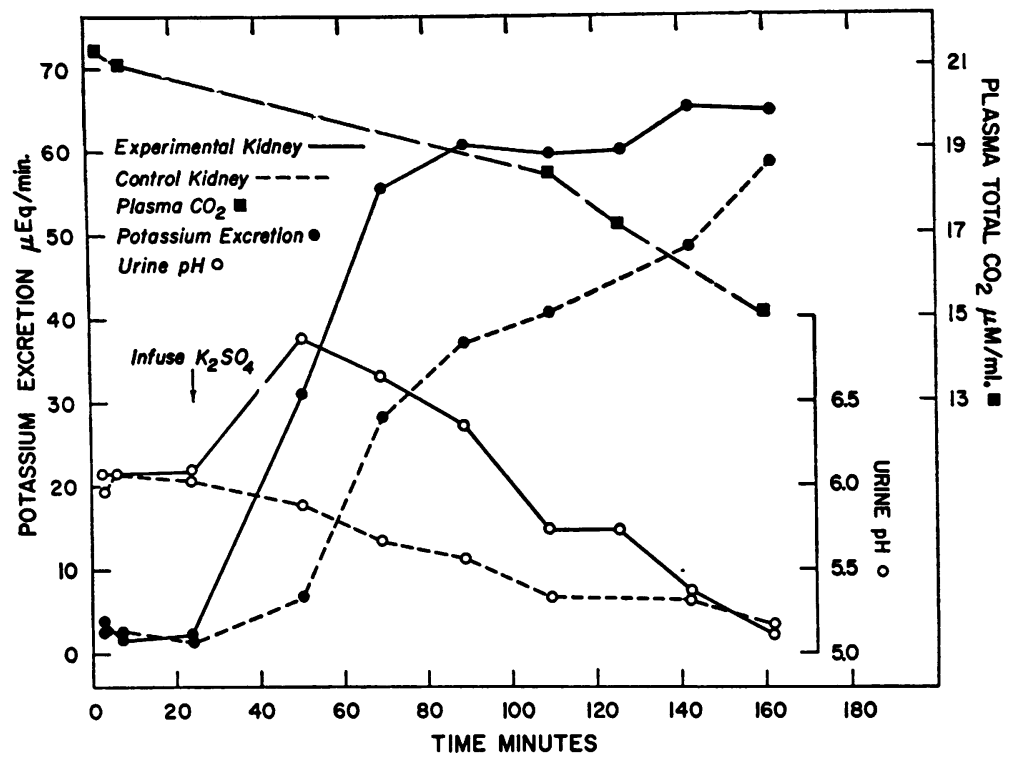

Fig. 2. EFfect of the Infusion of $\mathrm{K}_{2} \mathrm{SO}_{4}$ into the Leg Vein of a Chicken on the Excretion of Potassium, Urine pH, and Plasma Total $\mathrm{CO}_{2}$ Concentration

(14), a reduction in plasma bicarbonate insofar as it decreases the load of bicarbonate claiming reabsorption, will diminish the total hydrogen ion requirement for this process. Consequently a secondary fall in urine $\mathrm{pH}$, as noted in Figure 2 , may supervene as a result of the development of metabolic acidosis, despite a decrease in hydrogen ion secretion. Similar changes in plasma bicarbonate concentration and urine $\mathrm{pH}$ following injection of potassium have been observed in the rat and dog $(15,16)$. Metabolic acidosis presum- ably develops as a result of the extrusion of hydrogen ions from muscle and other nonrenal tissue cells in exchange for entering potassium (17-19) as well as to the loss of bicarbonate in the urine (20).

Effect of alterations in peritubular $\mathrm{pCO}_{2}$

Respiratory modifications of acid-base balance are known to affect the excretion of potassium and hydrogen ions (21-24). An increase in urine hydrogen ion concentration and a de-

TABLE IV

Effect of local rise in $\mathrm{pCO}_{2}$ on $\mathrm{K}^{+}$excretion and urine $\mathrm{pH}$

\begin{tabular}{|c|c|c|c|c|c|c|c|c|}
\hline \multirow[b]{2}{*}{$\begin{array}{l}\text { Time } \\
\min .\end{array}$} & \multirow[b]{2}{*}{$\begin{array}{c}\text { Plasma } \\
\mathrm{K}^{+} \\
m E q . / L .\end{array}$} & \multicolumn{3}{|c|}{ Control kidney } & \multicolumn{4}{|c|}{ Experimental kidney } \\
\hline & & $\begin{array}{l}\text { Plasma } \\
\text { flow } \\
\text { ml./min. }\end{array}$ & $\mathrm{pH}$ & $\underset{\mu E q . / m i n}{U_{K V}}$ & $\underset{m E q . / L .}{\mathrm{P}-\mathrm{T}^{+}}$ & $\begin{array}{c}\text { Plasma } \\
\text { flow } \\
\text { ml./min. }\end{array}$ & $\mathrm{pH}$ & $\underset{\mu E q . / m i n}{U_{K} V}$ \\
\hline-50 & \multicolumn{8}{|c|}{ Infuse $200 \mu \mathrm{Eq} . / \mathrm{min} . \mathrm{K}_{2} \mathrm{SO}_{4}$ into leg vein (experimental side) } \\
\hline $\begin{array}{c}0-8 \\
8-16 \\
16-25 \\
26-30\end{array}$ & $\begin{array}{l}4.3 \\
5.3 \\
6.5 \\
7.6\end{array}$ & $\begin{array}{l}44 \\
47 \\
47 \\
38\end{array}$ & $\begin{array}{l}4.51 \\
4.46 \\
4.59 \\
4.67\end{array}$ & $\begin{array}{l}49 \\
56 \\
49 \\
49\end{array}$ & $\begin{array}{r}9.6 \\
10.6 \\
12.9 \\
14.8\end{array}$ & $\begin{array}{l}37 \\
37 \\
31 \\
28\end{array}$ & $\begin{array}{l}5.93 \\
6.23 \\
5.67 \\
6.27\end{array}$ & $\begin{array}{l}72 \\
74 \\
69 \\
68\end{array}$ \\
\hline 30 & \multicolumn{8}{|c|}{ Infuse $300 \mu \mathrm{M} / \mathrm{min}$. acetic acid into leg vein. Continue $\mathrm{K}_{2} \mathrm{SO}_{4}$} \\
\hline $\begin{array}{l}34-44 \\
44-53 \\
54-63 \\
63-70\end{array}$ & $\begin{array}{l}8.3 \\
8.8 \\
9.3 \\
9.6\end{array}$ & $\begin{array}{l}36 \\
31 \\
32 \\
35\end{array}$ & $\begin{array}{l}5.05 \\
5.21 \\
4.85 \\
4.72\end{array}$ & $\begin{array}{l}52 \\
54 \\
58 \\
47\end{array}$ & $\begin{array}{l}13.6 \\
14.5 \\
15.2 \\
15.2\end{array}$ & $\begin{array}{l}38 \\
35 \\
34 \\
36\end{array}$ & $\begin{array}{l}5.18 \\
4.95 \\
4.92 \\
4.66\end{array}$ & $\begin{array}{l}45 \\
39 \\
38 \\
35\end{array}$ \\
\hline
\end{tabular}

* P-T refers to peritubular plasma $\mathrm{K}^{+}$concentration. 
crease in potassium excretion have been observed in respiratory acidosis, and the converse in alkalosis. The effects are thought to be secondary to alterations in renal tubule cell $\mathrm{pCO}_{2}$ conditioned by parallel changes in the $\mathrm{pCO}_{2}$ of renal blood and interstitial tissue. The rise in intracellular $\mathrm{pCO}_{2}$ and hydrogen ion concentration in respiratory acidosis accelerates the transfer of hydrogen ion into urine, inhibiting the transfer of potassium in the process. Analogous effects due to local changes in peritubular $\mathrm{pCO}_{2}$ are illustrated in the experiment detailed in Table IV. Potassium sulfate was injected into one leg vein. This, as always, resulted in a marked augmentation of potassium excretion on that side and a fall in urine hydrogen ion concentration. After 80 minutes, $300 \mu \mathrm{M}$ per minute of acetic acid was added to the potassium sulfate infusion. A prompt decrease in potassium excretion and a rise in urine hydrogen ion concentration occurred on the experimental side. Although acidosis (plasma total $\mathrm{CO}_{2} 17$ to $18 \mathrm{mEq}$. per L.) due to the administration of potassium was present prior to the infusion of acetic acid, the urinary effects are clearly due to a rise in the $\mathrm{pCO}_{2}$ of the peritubular tissue and are not conditioned by changes in systemic acid-base balance. Subsequent conversion of acetate to bicarbonate apparently prevents the development of a greater degree of metabolic acidosis. Similar results were observed in five other studies. The rise in $\mathrm{H}_{2} \mathrm{CO}_{3}$ concentration and $\mathrm{pCO}_{2}$ of peritubular plasma is due to the interaction of acetic with bicarbonate in blood. The $\mathrm{CO}_{2}$ excess escapes into the first capillary bed to which the blood is delivered, that of the peritubular region, and since $\mathrm{CO}_{2}$ is freely diffusible there is a concomitant rise in tubule cell $\mathrm{pCO}_{2}$ and hydrogen ion concentration. Addition of hydrochloric acid to renal portal venous blood evokes the same response. Local tubule cell "respiratory" acidosis occurs as with acetic acid, although in this instance it is probable that a greater degree of systemic metabolic acidosis develops.

The converse experiment, addition of sodium hydroxide to saphenous vein blood to lower the $\mathrm{pCO}_{2}$ of the cells, was generally unsatisfactory. The experiments were frequently lethal and it was not possible to demonstrate an unequivocal unilateral effect. Furthermore, a marked rise in plasma bicarbonate (and therefore filtered load of bicarbonate) resulted in bilateral alkalinization of the urine and kaluresis, not unlike that noted when an infusion of sodium bicarbonate is administered into wing vein.

Unilateral alkalinization of the urine is not observed if sodium bicarbonate is introduced into the renal portal circulation although this has

TABLE V

Effect of Salyrgan ${ }^{\circledR}$ on electrolyte excretion

\begin{tabular}{|c|c|c|c|c|c|c|c|c|}
\hline \multirow[b]{2}{*}{$\begin{array}{l}\text { Time } \\
\text { min. }\end{array}$} & \multicolumn{4}{|c|}{ Control kidney } & \multicolumn{4}{|c|}{ Experimental kidney } \\
\hline & $\begin{array}{c}\text { Filt.* } \\
\mathrm{K}^{+}\end{array}$ & $\mathrm{U}_{\mathbf{\mu}} \mathrm{V}_{\boldsymbol{q}}$ & $\mathrm{U}_{\mathrm{NaV}}$ & UciV & $\underset{\mathrm{K}^{+}}{\text {Filt. }}$ & $\underset{\mu E}{\mathrm{U}_{\mathrm{K}} \mathrm{V}}$ & $\mathrm{UnN}_{\text {in. }}$ & $\mathrm{UalV}$ \\
\hline-20 & \multicolumn{8}{|c|}{ Infuse $100 \mu \mathrm{M} / \mathrm{min} . \mathrm{KCl}$ into leg vein (experimental side) } \\
\hline $\begin{array}{r}0-30 \\
31-46 \\
47-70\end{array}$ & $\begin{array}{l}18 \\
18 \\
16\end{array}$ & $\begin{array}{r}9 \\
9 \\
10\end{array}$ & $\begin{array}{l}3 \\
5 \\
6\end{array}$ & $\begin{array}{l}10 \\
12 \\
14\end{array}$ & $\begin{array}{l}17 \\
18 \\
18\end{array}$ & $\begin{array}{l}22 \\
38 \\
37\end{array}$ & $\begin{array}{l}3 \\
4 \\
4\end{array}$ & $\begin{array}{l}20 \\
33 \\
29\end{array}$ \\
\hline 88 & \multicolumn{8}{|c|}{$\begin{array}{l}\text { Infuse } 0.3 \mathrm{ml} \text {. Salyrgan }{ }^{\circledR} \text { followed by } .005 \mathrm{ml} . / \mathrm{min} \text {. into wing vein. } \\
\text { Continue } \mathrm{KCl}\end{array}$} \\
\hline $\begin{array}{r}82-101 \\
101-108 \\
108-113 \\
113-117\end{array}$ & $\begin{array}{l}19 \\
18 \\
20 \\
23\end{array}$ & $\begin{array}{l}8 \\
6 \\
5 \\
5\end{array}$ & $\begin{array}{l}15 \\
25 \\
37 \\
49\end{array}$ & $\begin{array}{l}14 \\
26 \\
37 \\
49\end{array}$ & $\begin{array}{l}20 \\
22 \\
22 \\
23\end{array}$ & $\begin{array}{l}18 \\
12 \\
11 \\
11\end{array}$ & $\begin{array}{l}20 \\
31 \\
42 \\
57\end{array}$ & $\begin{array}{l}22 \\
37 \\
51 \\
60\end{array}$ \\
\hline 127 & \multicolumn{8}{|c|}{ Inject $20 \mathrm{mg}$. dimercaprol (BAL) intramuscularly } \\
\hline $\begin{array}{l}125-130 \\
131-138 \\
138-145\end{array}$ & $\begin{array}{l}22 \\
22 \\
19\end{array}$ & $\begin{array}{l}22 \\
20 \\
18\end{array}$ & $\begin{array}{r}25 \\
15 \\
9\end{array}$ & $\begin{array}{l}36 \\
27 \\
19\end{array}$ & $\begin{array}{l}25 \\
22 \\
22\end{array}$ & $\begin{array}{l}34 \\
32 \\
31\end{array}$ & $\begin{array}{l}32 \\
23 \\
15\end{array}$ & $\begin{array}{l}- \\
49 \\
39\end{array}$ \\
\hline
\end{tabular}

* Filtered $\mathrm{K}^{+}=\mathrm{GFR} \times$ plasma $\mathrm{K}^{+}$concentration. 


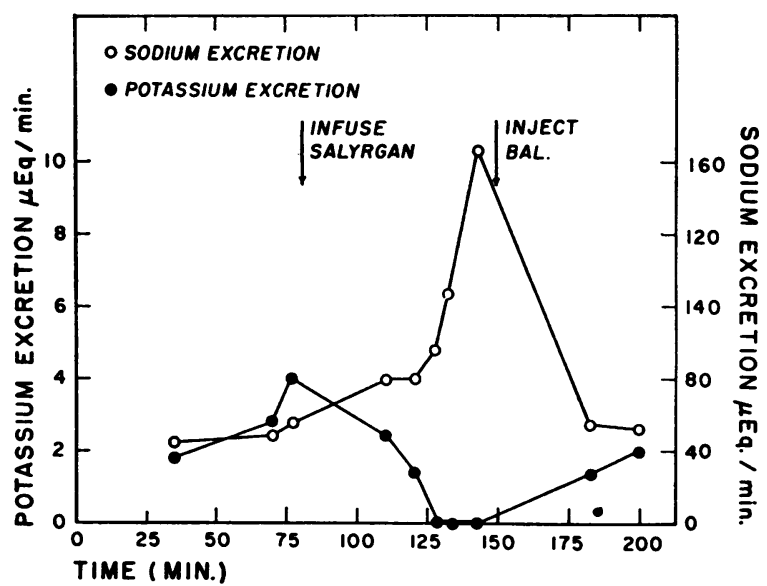

Fig. 3. Effect of Salyrgan on the Total UriNary ExCRetion of Sodium and Potassium in the Chicken

been reported in the frog (25). Instead, bilateral alkalinization and kaluresis develop when the filtered load of bicarbonate rises. This occurs despite the fact that the $\mathrm{pCO}_{2}$ on the infused side is undoubtedly somewhat greater than on the control side. However, if the $\mathrm{pCO}_{2}$ is further elevated by addition of acetic acid, the usual reduction in potassium excretion is noted.

\section{Effect of Salyrgan ${ }^{\circledR}$}

Direct and reversible inhibition of potassium excretion by mercurial diuretics has been observed repeatedly $(2,26)$. Whether this is due to enhanced reabsorption of potassium or diminished secretion or both has not been entirely clear. Furthermore, mercury does not depress potassium excretion under all circumstances in these species, complicating the interpretation of results. These difficulties are not encountered in the chicken. The filtration fraction is so low $(0.05)$ that the potential contribution of filtered and nonreabsorbed potassium to that excreted is minimal. Also, mercury uniformly depresses potassium excretion in this animal, irrespective of the initial rate of excretion.

The effect of Salyrgan is illustrated in Table V. Potassium excretion was initially augmented by the injection of potassium chloride. The injection of $0.3 \mathrm{ml}$. Salyrgan ${ }^{8}$ caused a rapid fall in potassium excretion which was reversed by 20 mg. dimercaprol [BAL (British anti-Lewisite)]. The decrement in potassium excretion was greater than could be accounted for by increased reabsorption, clearly denoting that the mercurial interfered with the secretory process.

In contrast to studies in dog and man in which mercury increases potassium excretion when it is initially low (26), in the chicken Salyrgan ${ }^{\circledR}$ interferes with excretion under these circumstances as well. In the study illustrated in Figure 3, potassium virtually disappeared from the urine following Salyrgan ${ }^{\circledR}$. This observation limits the effect of mercury in this species to interference with secretion. Furthermore it is consistent with the view that all filtered potassium is reabsorbed, as had been suggested on the basis of other data in the dog (27). The low basal rate of potassium excretion in the control periods therefore probably represents secreted potassium only.

\section{DISCUSSION}

It has been suggested in previous publications that potassium and hydrogen ions are secreted into urine in exchange for sodium and that these ions compete for some portion of the exchange process by which sodium is reabsorbed (10). The data obtained in these studies constitute additional support for this thesis. Furthermore they afford direct and unequivocal evidence that the transfer of potassium and hydrogen ions into urine is conditioned by alterations in the peritubular concentrations (and therefore presumably the renal tubule cell concentrations) of these ions and not necessarily by extrarenal (systemic) changes in acid-base balance. The latter are of importance, however, insofar as they affect the filtered load and tubule cell concentrations of electrolytes.

Linked transfer of hydrogen, potassium and sodium ions is thought to be effected by specific and reversible combination with a carrier. Although no direct evidence for this exists, the results of these and other studies are consistent with this view. The observations that the process may be saturated (presumably indicating enzyme or carrier limitation), that it is subject to competitive inhibition, and finally that it may be interfered with in a reversible manner by a pharmacologic agent, are best interpreted within the framework of the carrier hypothesis. These arguments will be discussed separately, but first 
it should be noted that none of the data affords any insight into the precise nature of the mechanism, that is whether the ions are actively or passively transported. Neither the demonstration of net potassium secretion nor the observation that the concentration of potassium in urine exceeds that of plasma is sufficient evidence to conclude that potassium is transported by an active process. Demonstration of active transport, movement of an ion against its electrochemical gradient (28), requires knowledge of the chemical gradient in the pertinent area and the transtubular potential. Despite the lack of this information, it is relatively certain that linked transfer by a carrier does occur and that at least one of the cations involved is transported against its electrochemical gradient.

It is clear from the experiments illustrated in Table I and Figure 1 that the excretion of potassium is a function of its peritubular concentration. Since the filtered load of potassium is equal on both sides, the unilateral changes noted in these studies can only be due to alterations in tubule cell transport induced by the higher concentration of potassium. Of greater significance in the context of this discussion is the observation that at high concentrations of peritubular potassium the relationship between urinary excretion and plasma concentration is no longer linear (Figure 2). Excretion clearly approaches a maximal rate, indicating that the transport mechanism may be saturated and that passive diffusion from plasma to urine is not a rate-limiting step in the process. These data constitute strong support for the view that reversible combination with a carrier is involved in potassium transport and that association and dissociation of the carrier-cation complex is rate-limiting. The pertinence of a tubular transfer maximum in the chicken insofar as it relates to the mechanism of potassium transport in other species is not invalidated by the uniqueness of the finding, since only in this preparation is it possible to achieve the concentration of potassium in peritubular plasma necessary to saturate the process.

The reciprocal changes in hydrogen and potassium excretion induced by administration of potassium salts, acetazoleamide or acetic acid are indicative of the competitive nature of the transport process under study. Although similar conclusions had been derived from data in other species (10), the present studies clearly limit the locus of action of the changes responsible for the urinary effects. It is probable that the relationship between the concentrations of the cations in peritubular plasma (and presumably in tubule cells), rather than a reciprocal change in their concentrations, conditions the urinary response (29). Thus, although increased potassium excretion and interference with acidification following the infusion of potassium are probably associated with a reciprocal change in the intracellular concentrations of potassium and hydrogen ions, similar urinary effects due to acetazoleamide are most likely due to intracelluar alkalinization alone. Conversely, aciduria and decreased potassium excretion following introduction of acetic acid are a consequence of an increase in the $\mathrm{pCO}_{2}$ and hydrogen ion concentration of tubular cells. It is unlikely that cell potassium is appreciably altered in this situation. The hypothetical carrier is assumed to form a complex to a lesser or greater extent with hydrogen or potassium as a function of the intracellular ratio of these ions, the relative preponderance of either ion within the tubular cell determining which is preferentially secreted in exchange for sodium.

The effect of the unilateral infusion of sodium bicarbonate is somewhat anomalous. Rather than observing unilateral alkalinization, as had been reported in the frog (25), bilateral alkalinization and kaluresis occur in association with a rise in filtered bicarbonate. The result differs in no way from the response to the systemic infusion of bicarbonate in either chicken or dog. Were the cell membrane impermeable to bicarbonate, as may be inferred from the data of Wallace and Hastings (30) in muscle, the absence of a unilateral effect would be understandable. However it would then be difficult to account for bilateral alkalinization and kaluresis in the context of the present hypothesis regarding competition between hydrogen and potassium ions. Furthermore the $\mathrm{pCO}_{2}$ of peritubular plasma is elevated when bicarbonate is added to renal portal blood, and this should, if anything, elicit the reverse: acidification and a fall in potassium excretion. If on the other hand one assumes, on the basis of the observation of bicarbonate uptake by cortical slices by Anderson and Mudge (31), that bi- 
carbonate does in fact penetrate the tubule cells, it is possible that the rise in $\mathrm{pCO}_{2}$ is sufficient (despite an increase in cell bicarbonate) to augment hydrogen ion secretion unilaterally and to mask any effect on urine $\mathrm{pH}$ and potassium excretion produced by the transfer of bicarbonate into cells. On the other hand, as previously noted, when bicarbonate is infused into the wing vein of the chicken, bilateral kaluresis and alkalinization occurs. Since the rise in $\mathrm{pCO}_{2}$ under these circumstances may be less due to interposition of the lungs, it is possible that intracellular alkalinization may be implicated as the factor responsible for the urinary changes.

Alternatively none of the effects noted in the urine need necessarily derive from changes in intracellular composition. Merely increasing the load of sodium presented to the site in the distal segment where potassium is transferred in exchange for sodium will augment potassium excretion. This occurs in other forms of solute diuresis and if secondary to a rise in filtered bicarbonate, the increased concentrations of sodium and bicarbonate delivered to the distal segment could conceivably account for the alkalinization and kaluresis.

In any event the results of the administration of potassium, and the inhibitory effect of a rise in cell $\mathrm{pCO}_{2}$ on potassium excretion, may be viewed as evidence that the transport system is subject to competitive inhibition not unlike that which would be predicted were reversible combination of either ion with a carrier involved in the exchange process.

Mercurial diuretics, as noted earlier, had been thought to affect both the reabsorption and secretion of potassium in dog and man (2). This was based on the divergent effects of the drug on potassium excretion dependent on the initial level of excretion. Recently evidence has been presented demonstrating that the drug interferes with secretion alone (27). The data obtained in these studies may be interpreted as indicating that the only effect of mercury in the chicken is to interfere with the secretory process. Furthermore the complete abolition of potassium excretion observed (Figure 3) supports the view that all filtered potassium is reabsorbed. The rise in potassium excretion noted after mercury in the dog, when the initial rate of potassium ex- cretion is low, may be a reflection of the increased load of sodium presented to a partially inhibited but unsaturated exchange site. The increased load of sodium provides more opportunity for exchange, even though the process proceeds at less than maximal efficiency.

\section{CONCLUSIONS}

The secretion of potassium into urine is inversely related to that of hydrogen ion in the chicken as in other species. Alterations in the secretory rates of potassium and hydrogen ions are mediated by changes in the peritubular (and/ or the renal intracellular) concentrations of these ions and are not necessarily related to changes in systemic acid-base balance.

The secretory mechanism for potassium may be saturated, is subject to competitive inhibition, and is interfered with in a reversible fashion by mercury, a pharmacologic inhibitor.

The data have been interpreted as indicating that linked transfer of potassium, hydrogen and sodium ions is probably accomplished by a carrier mechanism. Association and dissociation of the hypothetical cation-carrier complex is apparently rate-limiting in the transport process. Preferential association of either potassium or hydrogen ions with the carrier may be a function of the relative preponderance of one or the other ion within the tubule cell.

\section{REFERENCES}

1. Berliner, R. W., Kennedy, T. J., Jr., and Hilton, J. G. Renal mechanisms for excretion of potassium. Amer. J. Physiol. 1950, 162, 348.

2. Mudge, G. H., Ames, A., III, Foulks, J., and Gilman, A. Effect of drugs on renal secretion of potassium in the dog. Amer. J. Physiol. 1950, 161, 151.

3. Sperber, I. Investigations on the circulatory system of the avian kidney. Zool. Bidr. Uppsala 1948, 27, 429.

4. Sperber, I. A new method for the study of renal tubular excretion in birds. Nature (Lond.) 1946, 158, 131.

5. Walser, M., Davidson, D. G., and Orloff, J. The renal clearance of alkali-stable inulin. $\mathrm{J}$. clin. Invest. 1955, 34, 1520.

6. Bratton, A. C., and Marshall, E. K., Jr. A new coupling component for sulfanilamide determination. J. biol. Chem. 1939, 128, 537.

7. Cotlove, E., Trantham, H. V., and Bowman, R. L. An instrument and method for automatic, rapid, accurate, and sensitive titration of chloride in biologic samples. J. Lab. clin. Med. 1958, 51, 461. 
8. Van Slyke, D. D., and Neill, J. M. The determination of gases in blood and other solutions by vacuum extraction and manometric measurement. I. J. biol. Chem. 1924, 61, 523.

9. Wolbach, R. A. Renal regulation of acid-base balance in the chicken. Amer. J. Physiol. 1955, 181, 149.

10. Berliner, R. W., Kennedy, T. J., Jr., and Orloff, J. Relationship between acidification of the urine and potassium metabolism; effect of carbonic anhydrase inhibition on potassium excretion. Amer. J. Med. 1951, 11, 274.

11. Friedberg, C. K., Halpern, M., and Taymor, R. The effect of intravenously administered 6063 , the carbonic anhydrase inhibitor, 2 acetylamino-1,3,4-thiadiazole-5-sulfonamide, on fluid and electrolytes in normal subjects and patients with congestive heart failure. J. clin. Invest. 1952, 31, 1074.

12. Winkler, A. W., and Smith, P. K. Renal excretion of potassium salts. Amer. J. Physiol. 1942, 138, 94.

13. Loeb, R. F., Atchley, D. W., Richards, D. W., Benedict, E. M., and Driscoll, M. E. On the mechanism of nephrotic edema. J. clin. Invest. 1932, 11, 621.

14. Pitts, R. F., and Lotspeich, W. D. Bicarbonate and the renal regulation of acid base balance. Amer. J. Physiol. 1946, 147, 138.

15. Leonard, E., and Orloff, J. Regulation of ammonia excretion in the rat. Amer. J. Physiol. 1955, 182, 131.

16. Roberts, K. E., Magida, M. G., and Pitts, R. F. Relationship between potassium and bicarbonate in blood and urine. Amer. J. Physiol. 1953, 172, 47.

17. Darrow, D. C., Schwartz, R., Iaunucci, J. F., and Coville, $F$. The relation of serum bicarbonate concentration to muscle composition. J. clin. Invest. 1948, 27, 198.

18. Cooke, R. E., Segar, W. E., Cheek, D. B., Coville, F. E., and Darrow, D. C. The extrarenal correction of alkalosis associated with potassium deficiency. J. clin. Invest. 1952, 31, 798.
19. Orloff, J., Kennedy, T. J., Jr., and Berliner, R. W. The effect of potassium in nephrectomized rats with hypokalemic alkalosis. J. clin. Invest. 1953, $32,538$.

20. Bourdillon, J. Distribution in body fluids and excretion of ingested ammonium chloride, potassium chloride, and sodium chloride. Amer. J. Physiol. 1937, 120, 411.

21. Elkinton, J. R., Singer, R. B., Barker, E. S., and Clark, J. K. Effects of acute respiratory acidosis on electrolyte excretion in man. Fed. Proc. 1953, 12, 38.

22. Dorman, P. J., Sullivan, W. J., and Pitts, R. F. The renal response to acute respiratory acidosis. $\mathrm{J}$. clin. Invest. 1954, 33, 82.

23. McCance, R. A., and Widdowson, E. M. The response of the kidney to an alkalosis during salt deficiency. Proc. roy. Soc. B 1936, 120, 228.

24. Stanbury, S. W., and Thomson, A. E. The renal response to respiratory alkalosis. Clin. Sci. 1952, $11,357$.

25. Chambers, R., and Kempton, R. T. The elimination of neutral red by the frog's kidney. J. cell. comp. Physiol. 1937, 10, 199.

26. Berliner, R. W., and Kennedy, T. J., Jr. Renal tubular secretion of potassium in the normal dog. Proc. soc. Exp. Biol. (N. Y.) 1948, 67, 542.

27. Davidson, D. G., Levinsky, N. G., and Berliner, R. W. Maintenance of potassium excretion despite reduction of glomerular filtration during sodium diuresis. J. clin. Invest. 1958, 37, 548.

28. Ussing, H. H. Transport of ions across cellular membranes. Physiol. Rev. 1949, 29, 127.

29. Orloff, J. The role of the kidney in the regulation of acid-base balance. Yale J. Biol. Med. 1956, 29, 211.

30. Wallace, W. M., and Hastings, A. B. The distribution of bicarbonate ion in mammalian muscle. J. biol. Chem. 1942, 144, 637.

31. Anderson, H. M., and Mudge, G. H. The effect of potassium on intracellular bicarbonate in slices of kidney cortex. J. clin. Invest. 1955, 34, 1691. 